\title{
APPLICATION OF MAGNETIC AND INDUCED POLARIZATION METHOD FOR DELINEATING GOLD-BEARING VEIN ZONES AT CIBALIUNG, PANDEGLANG REGENCY, BANTEN
}

\author{
APLIKASI METODE MAGNETIK DAN INDUCED POLARIZATION \\ UNTUK MENDELINEASI ZONA VEIN MENGANDUNG EMAS DI \\ CIBALIUNG, KABUPATEN PANDEGLANG, BANTEN
}

\author{
MUHAMMAD SIDIQ ${ }^{*}$, Y. YATINI ${ }^{1}$ and AGUS FAJRIN ${ }^{2}$ \\ ${ }^{1}$ Department of Geophysics, Universitas Pembangunan Nasional Veteran Yogyakarta \\ Jalan SWK 104, Condongcatur, Yogyakarta 55283 \\ *Corresponding e-mail: sidiamuhammad955@yahoo.com \\ ${ }_{2}^{2}$ PT. Antam Tbk Unit Geomin \\ Jalan Letjen TB Simatupang No.1, Tanjung Barat, Jakarta Selatan 12530.
}

\begin{abstract}
Magmatic processes occurred during the Miocene period caused the formation of epithermal gold deposits in Cibaliung area. The deposit has previously been investigated through geological surveys which basically only covers the surface aspect, so in this study a subsurface analysis was carried out through magnetic and IP surveys to determine the distribution and continuity of the gold deposits. The magnetic survey was conducted over an area of about $3 \mathrm{~km}^{2}$ with sampling interval $20 \mathrm{~m}$ east and 100 $\mathrm{m}$ north. The magnetic data were processed using Oasis Montaj with magnetic intensity map as an output, which was then interpreted to determine the presence of structures and magnetite destruction zones as mineralization clues. The IP survey was conducted on 20 east-west oriented lines with length of about $1.2 \mathrm{~km}$. The electrode configuration used is Wenner with $25 \mathrm{~m}$ spacing. IP data were processed using RES2DINV software to eliminate bad datum points and invert the apparent chargeability values into the true ones. IP data are then interpreted to clearly determine the position, direction, and distribution of gold mineralization body by detecting the presence of sulfide minerals as ligands carrying gold. Magnetic data analysis shows that gold mineralization tends to occur at low magnetic anomaly, ranging from $37 \mathrm{nT}$ to $240 \mathrm{nT}$ and generally associated with northwest-oriented structures. The mineralization zone is found in four main vein zones with resistivity and chargeability values $<51 \Omega \mathrm{m}$ and $>50 \mathrm{~ms}$
\end{abstract}

Keywords: hydrothermal alteration, gold mineralization, susceptibility, resistivity, chargeability.

\begin{abstract}
ABSTRAK
Aktifitas magmatisme yang terjadi pada zaman miosen telah menyebabkan terbentuknya endapan emas epitermal di daerah Cibaliung. Endapan emas tersebut sebelumnya telah diteliti melalui survei geologi yang pada dasarnya hanya mencakup aspek permukaan saja, sehingga pada penelitian ini dilakukan analisis bawah permukaan melalui survei magnetik dan IP untuk mengetahui penyebaran dan kemenerusan mineralisasi emas. Survei magnetik dilakukan pada area seluas kurang lebih $3 \mathrm{~km}^{2}$ dengan spasi antar titik 20 m ke timur dan 100 m ke utara. Data magnetik diolah menggunakan software Oasis Montaj sehingga dihasilkan peta intensitas magnet batuan yang kemudian diinterpretasi untuk menentukan keberadaan struktur dan zona hancuran magnetit sebagai petunjuk mineralisasi. Survei IP dilakukan pada 20 lintasan berorientasi barat-timur dengan panjang bentangan $1.2 \mathrm{~km}$. Konfigurasi elektroda yang digunakan adalah Wenner dengan spasi $25 \mathrm{~m}$. Data IP diolah menggunakan software RES2DINV untuk menghilangkan bad datum point dan menginversi nilai chargeabilitas semu menjadi nilai sebenarnya. Data IP kemudian diinterpretasi untuk mengetahui secara jelas posisi, arah, dan persebaran tubuh mineralisasi emas dengan cara mendeteksi kehadiran mineral sulfida sebagai ligan pembawa emas. Hasil analisis data magnetik menunjukkan bahwa zona mineralisasi emas memiliki
\end{abstract}


respon intensitas magnet dominan pada angka $37 n T$ hingga $240 n T$ dan umumnya berasosiasi dengan struktur yang berorientasi barat laut. Zona mineralisasi ditemukan pada tujuh jalur vein dengan nilai resistivitas dan chargeabilitas sebesar $<51 \Omega \mathrm{m}$ dan $>50 \mathrm{~ms}$.

Kata kunci: alterasi hidrotermal, mineralisasi emas, suseptibilitas, resistivitas, chargeabilitas.

\section{INTRODUCTION}

Gold is a precious metal commodity that is most sought after in the mining sector because of its high economic value. The relatively increasing need demands mining companies to further increase their gold assets through exploration activities.

One of the areas that potential for gold deposits is located at Cibaliung which is located in Pandeglang Regency, Banten. Gold mineralization at Cibaliung has previously been studied by several researchers, such as Angeles, Prihatmoko and Walker (2002), Harijoko et al. (2007), and Kurniawan and Hartono (2010). Field studies conducted by those researchers showed that gold mineralization was formed in quartz veins with andesitic to basaltic-andesitic lava as the host rock, covered by dacitic tuffs. The deposit is a low sulfidation epithermal with formation temperature ranging from 150 to $220^{\circ} \mathrm{C}$.

Research of Cibaliung gold deposits conducted by several previous authors basically only covers the surface aspect but has not yet reached the subsurface aspect. Therefore, magnetic and IP surveys were carried out in this study in order to determine the position, direction, and distribution of the gold mineralization zone below the surface through 2D and 3D modelling that had never been done before.

\section{Geological Setting}

The study area is located in low undulating morphology and moderate hills with topography ranging from $66 \mathrm{~m}$ to $210 \mathrm{~m}$. Low undulating morphology was formed by smectite-illite or smectite-chlorite alteration and moderate hilly morphology was formed by silicic alteration. The rock units in the study area are divided into two units, namely premineralization and post-mineralization. The pre-mineralization rock unit is part of the Honje Formation, which are andesite, volcanic breccias, and sedimentary deposits.
The pre-mineralization rock is completely covered unconformity by post-mineralization rock, which is dacitic tuff (Kurniawan and Hartono, 2010).

\section{Geological Structure}

The geological structures that can be identified around the research area are shear fractures as a result of compressive stress and gash fractures as a result of tensional stress. Shear fractures are indicated by a straight and even plane and are generally in pairs. Meanwhile, the gash fractures are indicated by a slightly open and rough plane. Other geological structures that can be found are right lateral strike-slip faults, left lateral strike-slip faults, and normal faults (Al Hapsi, 2017). Geological structures that have gold prospect are located in a structural corridor that has a northwest direction and is thought to be a graben or pull apart basin.

\section{Alteration and Mineralization}

Hydrothermal alteration can be interpreted as a very complex process involving changes in minerals, chemical properties, and textures in rocks (Pirajno, 1992). In connection with this study, the hydrothermal alteration can be destructive for magnetite minerals which is the main source of a magnetic anomaly in igneous rocks, resulting in the magnetic anomaly dropping in the vicinity of fluid infiltration zone. Hydrothermal alteration can also cause the formation of clay and sulfide minerals which can affect the resistivity and chargeability values.

Field studies show that there are five alteration zones that formed in the study area, those are quartz-alunite, pyrophyllite-dickite, kaolinitedickite, illite-smectite, and smectite-chlorite. The alteration zone of quartz-alunite, pyrophyllite-dickite, and kaolinite-dickite is identical to the advanced argillic alteration. Meanwhile, the illite-smectite and chloritesmectite zones are identical to the argillic and propylitic alteration, respectively. 


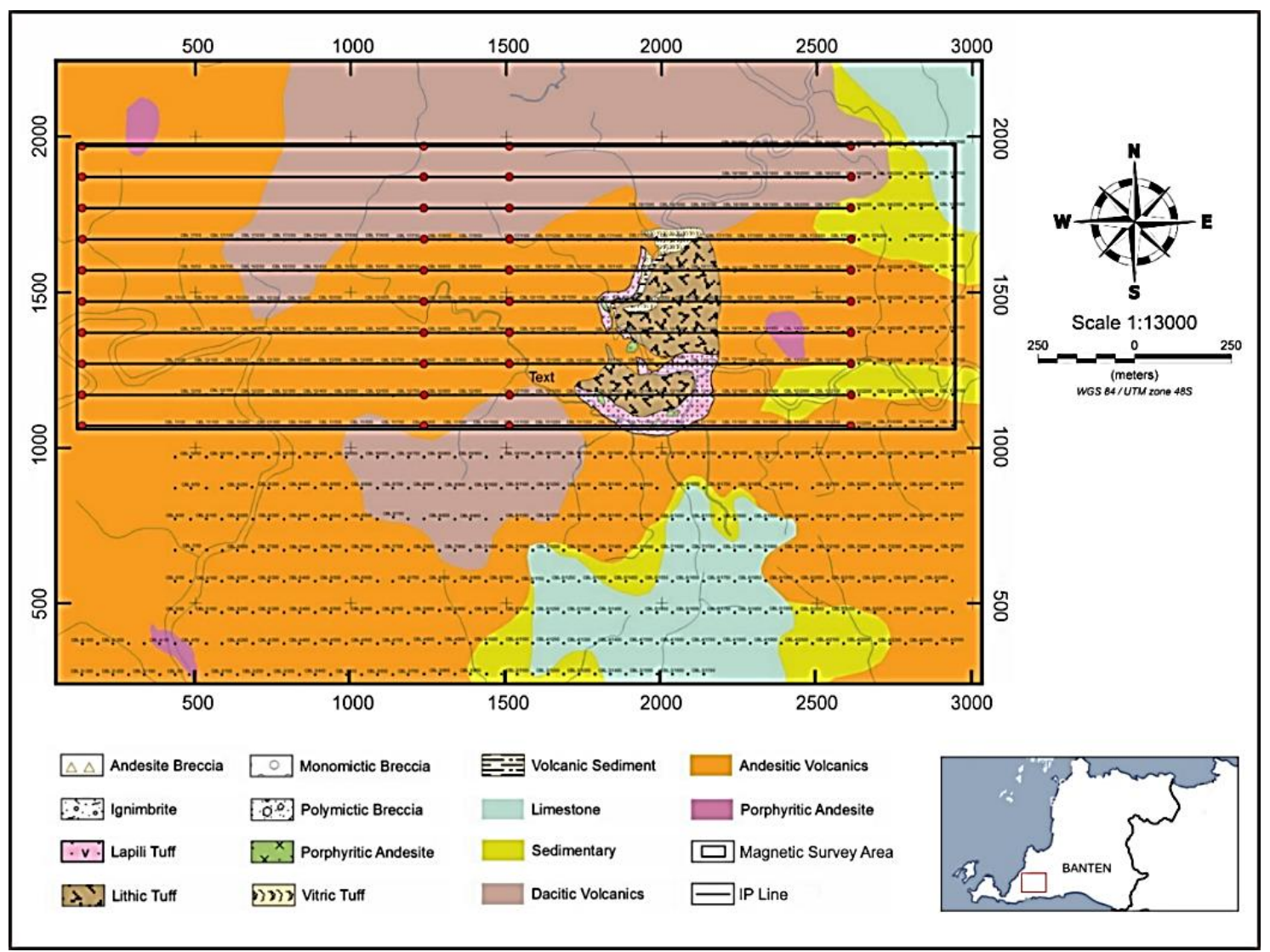

Figure 1. Geological map of study area

Angeles, Prihatmoko and Walker (2002) found that the mineralization occurred in Cibaliung area was formed in quartz veins with several textures, such as a stockworkmassive vein, crustiform-colloform vein, clay matrix breccia, and post-mineral fault gouge.

- Stockwork textures formed along the boundary of the main epithermal vein system. Massive vein texture consists of coarse quartz grains, adularia, calcite, and low amount sulfide.

- Crustiform-colloform texture consists of quartz and adularia which locally experience an increase in clay minerals of smectite and/or chlorite, calcite, and kaolinite. In this texture, clay and sulfide minerals are found with a fairly high gold concentration.

- Clay matrix breccia texture was formed from quartz-adularia veins embedded in clay minerals such as smectite and illite. A progressive decrease in the quartz content of breccias with high clay minerals indicates a decrease in fluid infiltration and is accompanied by a decrease in gold quality.
- Post-mineral fault gouge was a large enough fault that cut through a considerable amount of quartz veins. This texture is represented by quartz and wall rock fragments embedded in clay minerals like smectite, illite, and chlorite. Post-mineral fault gouges can contain significant gold mineralization.

\section{METHOD}

\section{Magnetic Method}

The magnetic method is based on the coulomb law which analogizes the magnetic pole (p) as an electric charge that is separated at a distance $r$, so that the magnetic field $(\mathrm{H})$ can be expressed as a magnetic force $(F)$ per unit pole (Telford, Geldart and Sheriff, 1991). The magnetic field strength can be expressed as follows.

$H=\frac{F}{P_{2}}=\frac{p_{1} p_{2}}{\mu r^{2} p_{2}} \hat{r}=\frac{p_{1}}{\mu r^{2}} \hat{r}$ 
Magnetic data acquisition was conducted using PPM Geometrics G-857 instrument over an area of approximately $3 \mathrm{~km}^{2}$. The acquisition technique chosen is the base rover, where one device is placed in a fixed position (Base) and the other device moves following the measurement points on survey design (Rover). The data acquisition was conducted by a grid-shaped measurement pattern, covering the survey area with 100 meters sampling interval to the north and 20 meters to the east, with total data collected about 2755 data. Sampling interval in the eastern direction is made higher so the northwest-southeast trending structures could be identified better, which is presumed to contain quite high gold mineralization (Angeles, Prihatmoko and Walker, 2002).

The magnetic data then through the quality checked process to remove the noise that can interfere with the signal and then corrected for the effects of main and external magnetic fields. The corrected magnetic data is then processed using the Geosoft Oasis Montaj software to form the magnetic anomaly map $(\mathrm{Ha})$ which will show the magnetic distribution of subsurface materials.
The magnetic anomaly map interpretation includes several filters, such as reduce to the equator (RTE), pseudogravity, total horizontal derivative (THD), and first vertical derivative (FVD).

RTE filter is used to eliminate the dipole effect caused by the asymmetric magnetization process (Figure 2). The dipole effect that is not eliminated can shift the anomaly from the actual position, which can cause errors in the interpretation.

The RTE map is then converted into a pseudogravity map through pseudogravity filter so that the THD filter can be applied. The THD map will show the total value of the horizontal gradient, where a relatively narrow and high gradient is interpreted as a structure. However, the narrow anomaly on the THD map is not clearly visible, so it is necessary to apply an FVD filter to enhance the position of the geological structure so that the interpretation of the structures could be carried out easier and better (Blakely, 1996). The changes of anomaly shape due to the applied pseudogravity and FVD filters can be seen in Figure 3.

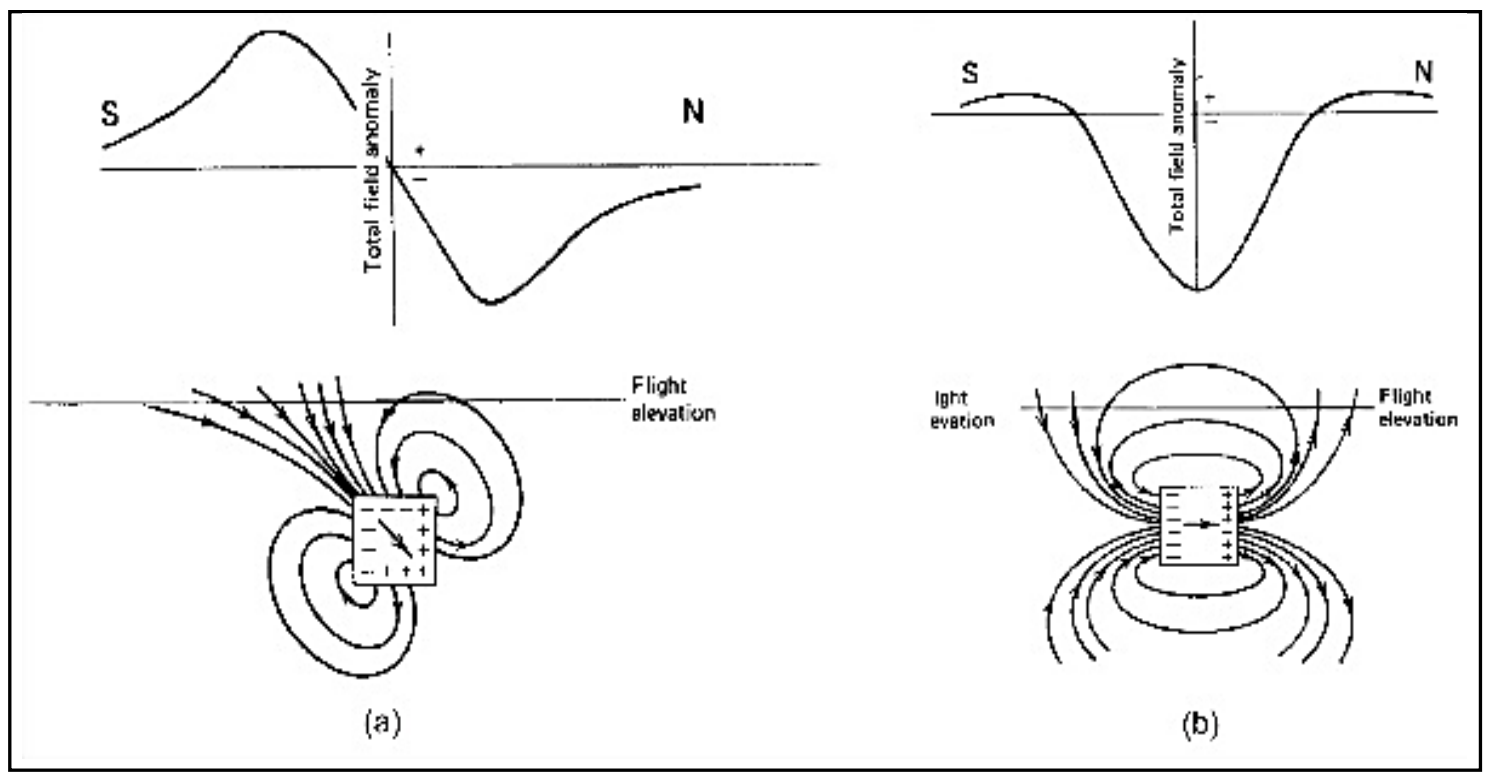

Figure 2. Magnetic anomaly before (a) and after RTE filtering (b) (Dobrin and Savit, 1988). 


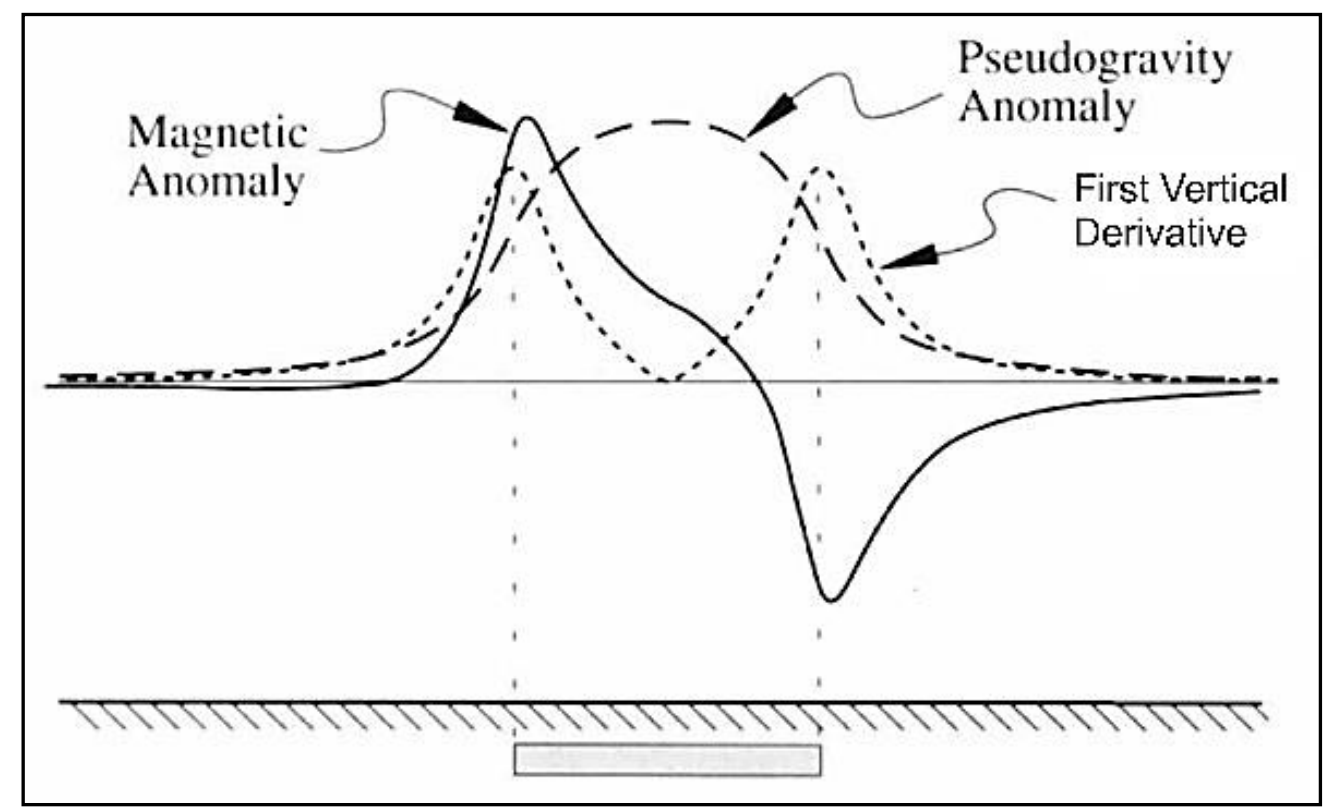

Figure 3. Pseudogravity anomaly and first vertical derivative caused by a tabular body. The pseudogravity anomaly will form a peak just above the anomaly source, while the first vertical derivative will have a peak just above the anomaly boundary (Modified from Blakely, 1996)

\section{Induced Polarization (IP) Method}

Induced Polarization is a phenomenon that is caused by electric current and is observed as a delayed voltage response due to the capacitive behavior of earth materials (Ward, 1990). An illustration of the IP effect can be seen through the sudden disconnection of the electric current injection in an electrode configuration. The voltage in the potential electrode generally does not immediately drop to zero but decays slowly over a few seconds or even up to several minutes. IP phenomena in rocks can arise due to the presence of metal minerals, narrowing of rock pores, and clay minerals in the pore channels.

The IP effect on the time domain can be calculated through the apparent chargeability value. The chargeability value that is measured on the IP instrument is the cumulative of several rock types and it is impossible to measure the response from only a certain rock, so the term apparent chargeability appears. The apparent chargeability value is obtained by calculating the area under the decay curve and dividing it by the total potential value (Figure 4). The amount of apparent chargeability value in a certain time interval can be formulated as follows.

$$
M_{a}=\frac{1}{V_{o}} \int_{t 1}^{t 2} V_{p}(t) d t
$$

$$
\text { Where } \begin{aligned}
\mathrm{Ma} & =\text { Apparent Chargeability } \\
\mathrm{Vp} & =\text { Polarization Potential } \\
\mathrm{V}_{0} & =\text { Total Potential Value } \\
\mathrm{t}_{1,2} & =\text { Time Interval }
\end{aligned}
$$

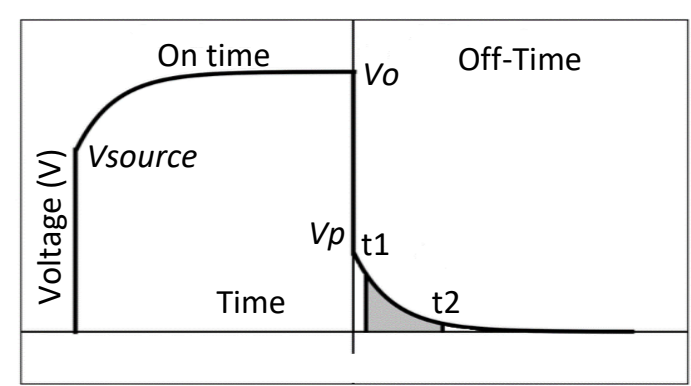

Figure 4. The overvoltage decay effect due to the current injection is switched off. (Modified from Kang and Oldenburg, 2018)

IP data acquisition was carried out using the SuperSting instrument on 20 IP lines with a length of $1.2 \mathrm{~km}$ for each line and a 25 meters spacing between the electrodes. Each IP line is coded as L1A, L1B, L2A, L2B, and so on up to L10B (Figure 5). The electrode configuration used in this study is the Wenner configuration with configuration factor $2 \pi а$. 


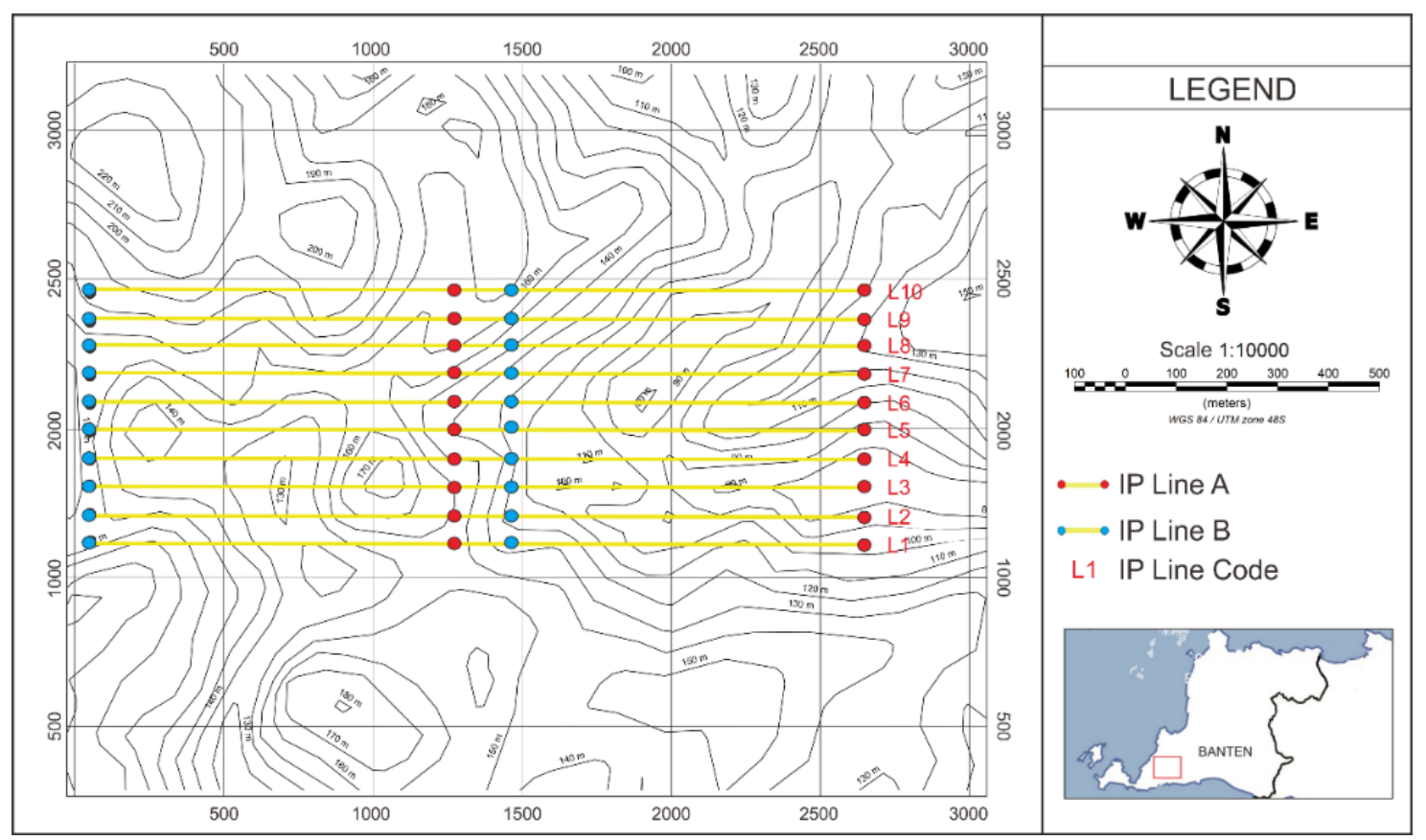

Figure 5. IP survey design with IP line A and B are intersecting each other

IP data processing and interpretation involve a series of processing steps, such as data quality control, IP data inversion, IP crosssection interpretation, cross-section correlation, and IP 3D modeling. Data quality control is carried out by observing the presence or absence of bad datum points in the resistivity data which is characterized by the presence of a large gap between one datum and another. In this study, the gap between datum points can exceed $500 \Omega$.m.

The IP data are then inverted using the RES2DINV software which aims to convert the apparent resistivity and chargeability values into true values. The IP sections are then interpreted to determine how alteration and mineralization in the study area affect the resistivity and chargeability values in the survey area. The interpretation ends with the delineation of mineralized vein zones and 3D modelling that is correlated with the magnetic data.

\section{RESULTS AND DISCUSSION}

\section{Alteration and Structures Interpretation}

The presence of gold in silica veins basically occurs in a very small percentage, making it impossible for magnetic methods to detect it directly. However, magnetic methods can still be used in gold exploration by determining the magnetite destructive zones which indicate hydrothermal alteration and sulfide activity as ligands that carrying gold. Magnetic methods are also used to determine the presence of structures in which the hydrothermal fluid pass through them, transporting and depositing the precious metal. Structural analysis is very important to do, considering that ore deposits in lowsulfidation epithermal systems are generally deposited as a cavity filling.

The interpretation of gold-mineralized zones is carried out by analyzing the distribution of magnetic anomaly, where the observed values ranging from $37.7 \mathrm{nT}$ to $437.6 \mathrm{nT}$ (Figure 6). Magnetic anomalies are then classified into three categories, low, medium, and high. This classification is based on how high the anomaly value compare to its maximum value.

Table 1. Classification and interpretation of magnetic anomaly in the study area.

\begin{tabular}{ccc}
\hline $\begin{array}{c}\text { Anomaly } \\
\text { Value }(\mathrm{nT})\end{array}$ & Category & Interpretation \\
\hline $37-240$ & Low & Highly altered \\
$241-310$ & Medium & Moderately altered \\
$311-437$ & High & Poorly altered \\
\hline
\end{tabular}




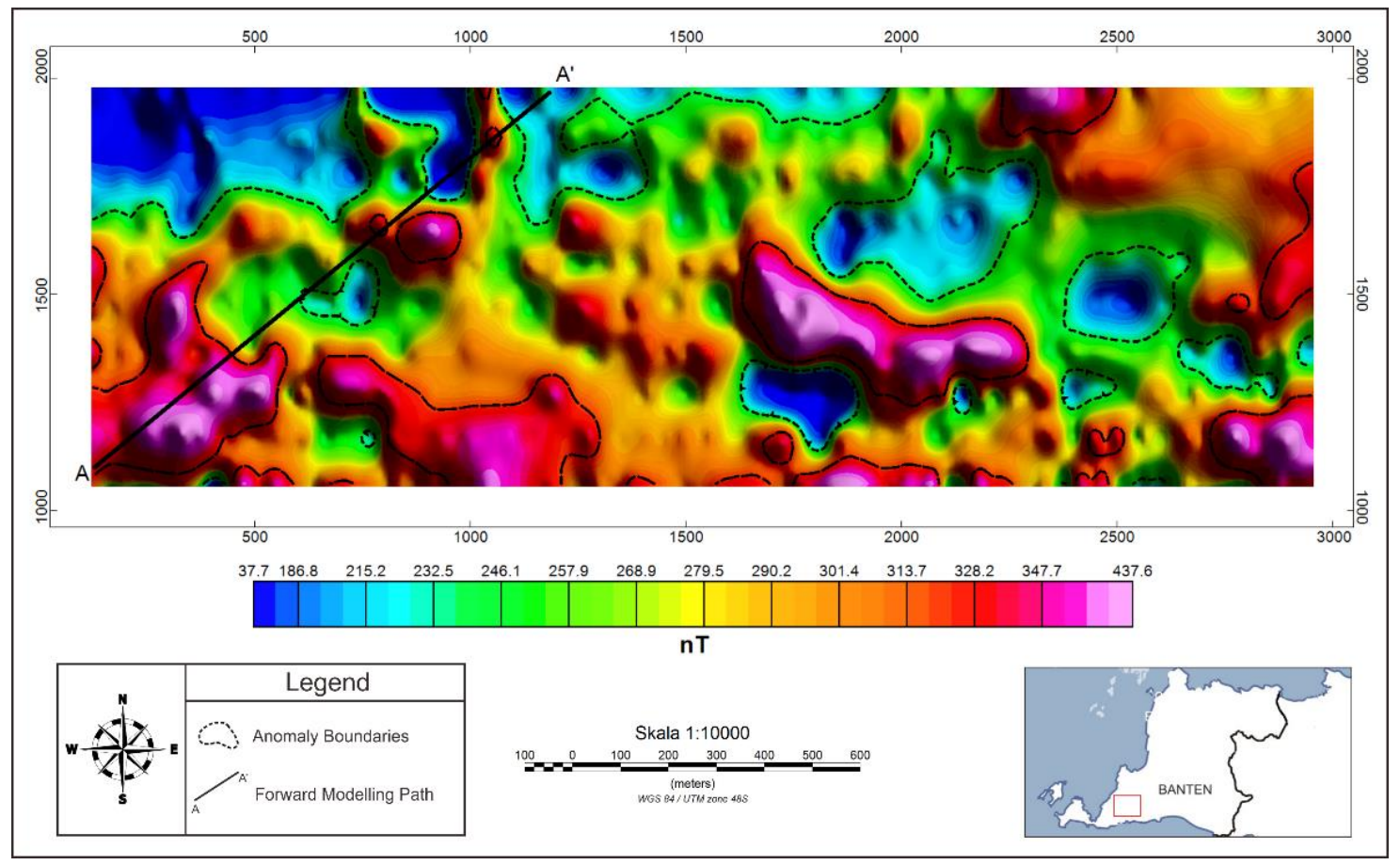

Figure 6. Magnetic anomaly map (Ha) of the study area

The presence of andesite-basaltic lava raises the initial hypothesis that, in an undisturbed geological condition, the magnetism of the igneous rock will be high, where the value of andesite susceptibility can reach $0.0127 \mathrm{cgs}$. The magnetic value of igneous rocks under normal circumstances depends on the mineral content they contained. The most important magnetic mineral found in maficultramafic and acidic rocks is magnetite, which can be destroyed by hydrothermal alteration processes. The chemical destruction of magnetite minerals can be caused by an oxidation process that will form hematite and a reaction to a sulfur-rich fluid which will form pyrite, where both minerals are nonmagnetic (Airo, 2002).

Analysis of the anomaly shows that there are some nonmagnetic bodies which are indicated by the blue area in the contour map. This low anomaly is thought to be a response due to the massive destruction of magnetite minerals in the rock, resulting in a significant decrease in the magnetic value of the original rock. The decrease in magnetic value can also be caused by the presence of diamagnetic minerals such as quartz, which will oppose the direction of magnetization. Anomalies with medium category observed on the anomaly map are interpreted as rocks with a less massive level of magnetite destruction so that they still show higher anomaly values than before. Meanwhile, high anomalies shown in red are interpreted as rocks with a very low degree of alteration.

The interpretation of the gold mineralization zone on the anomaly map is based on the fact that the gold metal is basically carried by hydrothermal fluids circulating in permeable rock. The hydrothermal fluid then alters and destroys the magnetite minerals in the rock and at the same time precipitates the metal minerals it contains along with the reduction of sulfide activity (Pirajno, 1992). The gold metal basically can't be detected directly by the magnetic survey, so in this case goldmineralized zones are detected through magnetic destructive zones.

The results of the analysis that have been presented previously can be used as a basis for saying that the main mineralization zones in the study area are associated with the low magnetic anomalies. However, this does not rule out the possibility that the goldmineralized zone can also be found in the medium or high anomaly, depending on how massive the magnetite destruction occurs. Low anomaly on the Ha map also cannot be generalized as a whole will contain gold, because alteration generally occurs widely and the possibility of silica mineral 
concentration which can reduce the magnetic anomaly value.

The interpretation of gold mineralization does not stop at the $\mathrm{Ha}$ map. The non-vertical magnetization process causes an asymmetric effect, where the anomaly on the Ha map is not exactly above the body of the source rock. Therefore, it is necessary to carry out a filtering process to eliminate the asymmetric effect. There are several filters that can be used, such as reduce to pole (RTP), reduce to equator (RTE) filters, and Analytic Signal. The RTE filter was chosen in this study because it is more suitable for magnetic data which has a west-east direction. Meanwhile, RTP and Analytic Signal filters will tend to form anomaly patterns that follow the magnetic data path itself.

Observations on the RTE map show changes in value as well as anomaly positions. The anomaly values now range from $62 \mathrm{nT}$ to 461 $\mathrm{nT}$. The interpretation of gold mineralization zones on the RTE map is basically the same as before, by searching for nonmagnetic rock bodies. However, the magnetic response given by the RTE map will be the opposite of the Ha map, where nonmagnetic rock bodies will give a high anomalous response and magnetic rock bodies will give low anomalous responses (Hinze et al., 2013). Therefore, the high anomaly response on the RTE map was chosen as a prospect area for gold mineralization (Figure 7).

Interpretation of the gold-mineralized zone is then carried out by looking for structures that act as the pathways for hydrothermal fluid and places where ore minerals are deposited. Basically, structure interpretation can be done on the RTE map, but not all of them can be detected as a result of shallow anomalies or noise which gives a masking effect to the anomalies below. Therefore, the RTE map will be processed further using a pseudogravity, total horizontal derivative (THD), and first vertical derivative (FVD) filter.

Pseudogravity filter is used to convert magnetic data into gravity fields using the Poisson's relation equation. Magnetic scalar potential of an element of magnetic material and the gravitational attraction of an element of mass have some obvious similarities, for example, they both have magnitudes that are inversely proportional to the squared distance to their respective point sources. Consider a body with uniform magnetization and uniform density, then the poisson's relation can be expressed as follows.

$$
V(P)=-\frac{M g_{m}}{\gamma \rho}
$$

$$
\begin{aligned}
& \text { Where } \begin{array}{ll}
\mathrm{V}(\mathrm{P}) & =\text { Magnetic scalar potential } \\
\mathrm{M} & =\text { Uniform magnetization } \\
g_{\mathrm{m}} & =\text { Component of gravity } \\
\gamma & =\text { Gravitational constant } \\
\rho & =\text { Density }
\end{array}
\end{aligned}
$$

A pseudogravity filter needs to be applied to magnetic data in order for a THD filter to be applied. The THD map derived from pseudogravity data is then further filtered using first vertical derivatives (FVD) to make a more narrow anomalies that have high gradients, so that the structure interpretation can be easier to do.

The structures on the FVD map are interpreted to have gradient values range from $0.01 \times 10^{-6}$ to $0.63 \times 10^{-6} \mathrm{mGal} / \mathrm{m}^{2}$ and are shown by the black dashed lines on Figure 8 . The level of gravity gradient in a structure is strongly influenced by how the pseudogravity value contrasts between the planes of the structure and the surrounding rocks. In addition, deeper structures will usually show weaker anomaly gradients due to higher frequency signals originating from shallow anomalies. The structures detected on the FVD map show the northwest and northeast orientations, where based on previous geological reviews, gold mineralized zones tend to form in northwest trending structures. The area around the structure is interpreted as gold prospect, considering that metal minerals in low-sulfidation epithermal systems tend to take the form of cavity filling.

\section{Depth Estimation and 2.5D Modeling}

The depth estimation and 2.5D modeling are also presented in this study. The depth of anomaly source in the $2.5 \mathrm{D}$ modeling was determined based on the power spectrum analysis carried out in Matlab and Microsoft Excel, as shown in Figure 9. The power spectrum analysis was performed on the A-A' profile with $1360 \mathrm{~m}$ in length and a sampling window of $20 \mathrm{~m}$ in spacing. The power spectrum data plot against the wave number shows three main data trends caused by anomalies at different depths. 
Application of Magnetic and Induced Polarization Method for Delineating... Muhammad Sidiq et al.

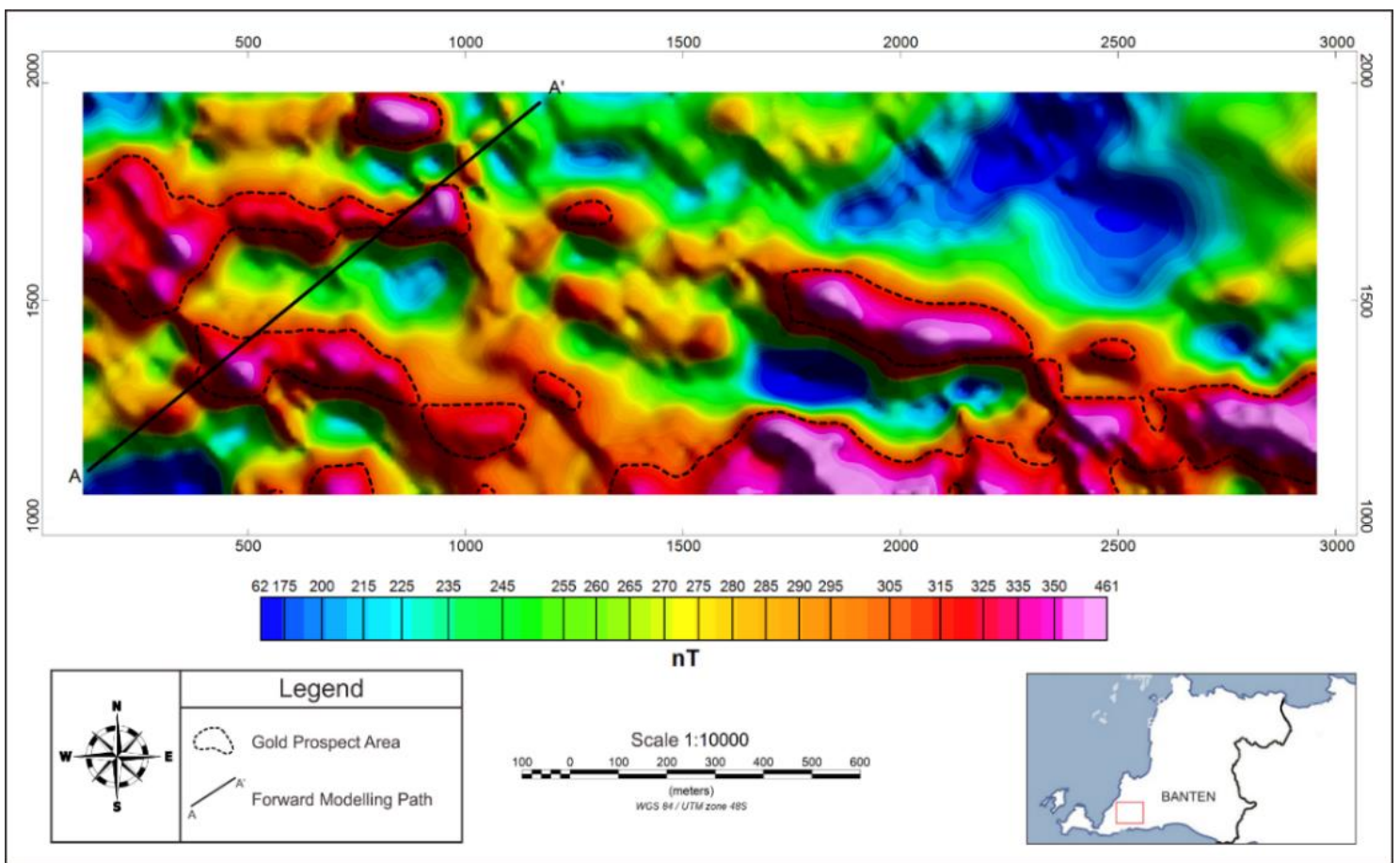

Figure 7. RTE map of the survey area with the prospect of mineralization suspected to be in a low magnetic zone

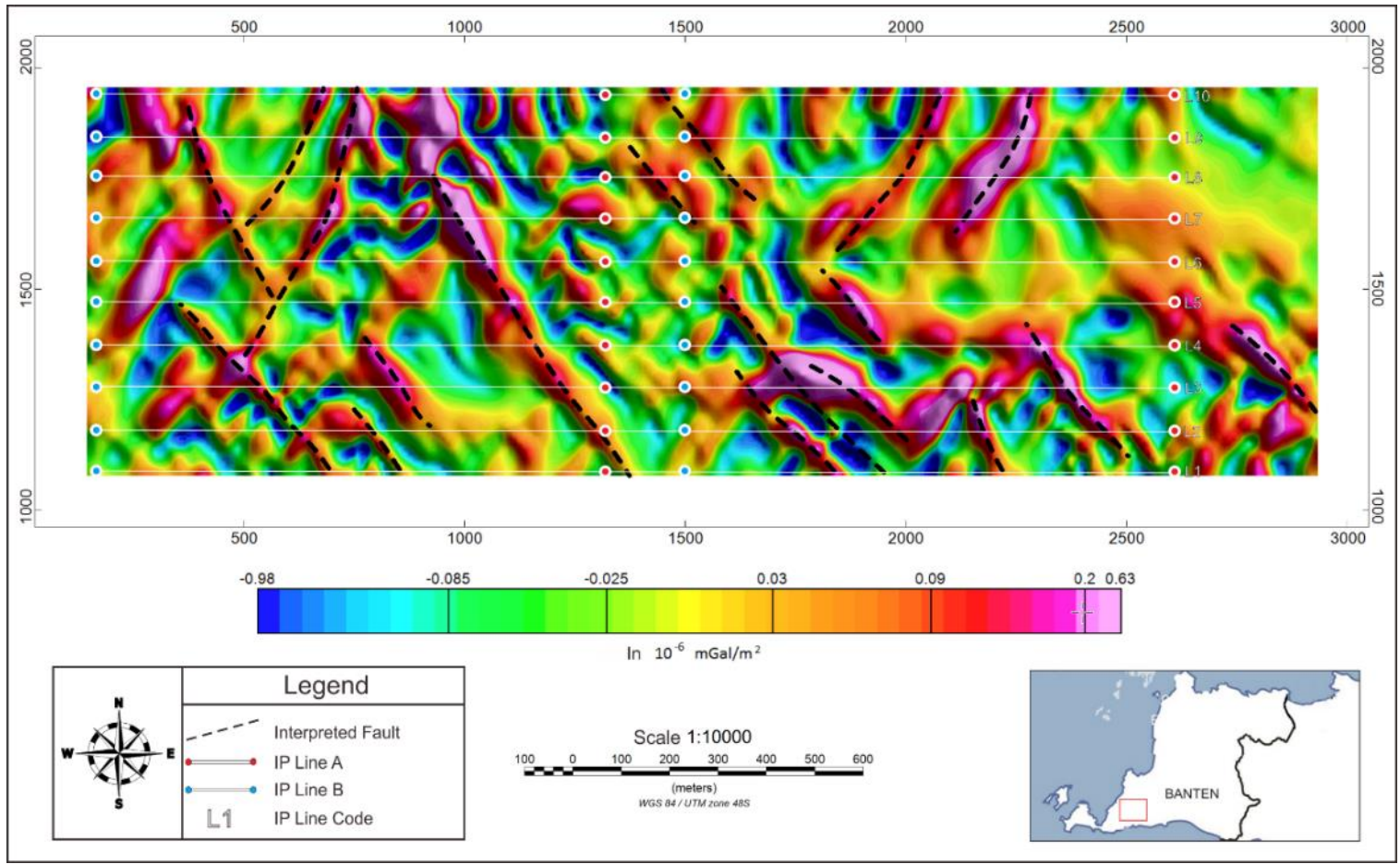

Figure 8. The FVD map of the study area with anomalous gradient values $0.01 \times 10^{-6}$ to $0.63 \times 10^{-6}$ $\mathrm{mGal} / \mathrm{m}^{2}$ is interpreted as a structure 


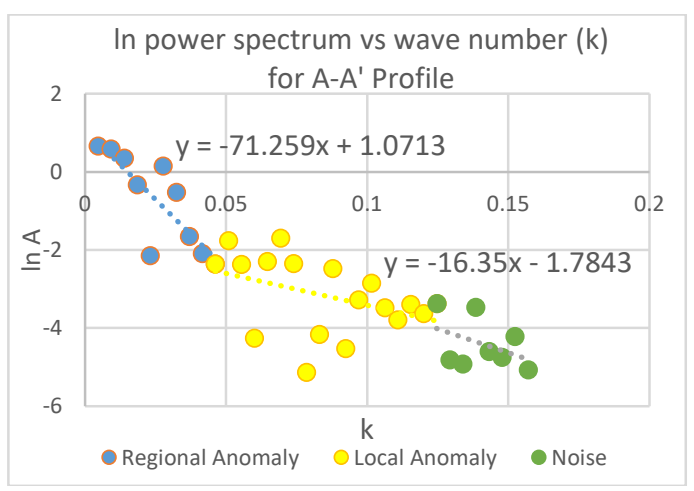

Figure 9. Power spectrum analysis graph for A-A' profile with regional anomaly depth about 385.8

$\mathrm{m}$ and local anomaly depth about $88.5 \mathrm{~m}$.

The first data trend is marked with a blue line and is interpreted as a regional anomaly with a surface depth of $385.8 \mathrm{~m}$. The second data trend is marked by a yellow line which is interpreted as a local anomaly with a surface depth of about $88.52 \mathrm{~m}$. Meanwhile, the third data trend is interpreted as noise because it has the highest wavenumber value.

The 2.5D modeling for $A-A^{\prime}$ profile was conducted using GM-SYS 2D modeling by giving the required inputto the software, including magnetic field strength, magnetic inclination, and magnetic declination of the survey area. The $2.5 \mathrm{D}$ modeling is made by estimating the susceptibility distribution of sub-surface material so that the calculated curve in the model can fit to the observed data curve.

The determination of susceptibility value in this 2.5D modeling was only based on trial and error, due to the absence of susceptibility data taken from rock samples in the survey area. Meanwhile, the susceptibility value found in the literature cannot be used as a reference in this modeling due to the different geological conditions and the alteration process that has changed the susceptibility value.

Analysis of the observed data (Figure 10) showed a decrease in magnetic anomalies on the middle side of $A-A^{\prime}$ profile. The magnetic anomaly which was initially around $350 \mathrm{nT}$ fell to $250 \mathrm{nT}$, where it was interpreted as a response of two rock blocks with different susceptibility. The west side of the profile is modeled as a Honje volcanic rock block with susceptibility $0.001751 \mathrm{cgs}$ and separated by a normal fault to the rock block on the middle side with susceptibility 0.002201 cgs.

Analysis on the east side of the profile shows a more fluctuating anomaly pattern, which is caused by more complex geological settings. The east side of the profile is modeled as a Honje volcanic rock block with susceptibility $0.003151 \mathrm{cgs}$ separated by a normal fault to the rock block on the middle side.

The type of fault in the 2.5D model is basically not determined by the observed magnetic anomaly but refers to the geological and mineralization models that have been made by Angeles, Prihatmoko and Walker (2002). Honje volcanic rock in model A-A' is completely covered by Cibaliung tuff with susceptibility $0.000001 \mathrm{cgs}$.

\section{Analysis and Delineation of Gold-Bearing Vein Zones}

The magnetic method that has been discussed previously is a regional method that is more intended for basic exploration, so it cannot be used to identify the presence of gold in veins in detail. The weakness of the magnetic method can be covered by the use of IP method which can specifically detect the presence of the gold deposits. The identification and delineation process is carried out by detecting the presence of sulfide minerals that are associated with the gold metal. This study also includes resistivity data which is used as support in the interpretation process.

The presence of gold mineralization in IP sections can be found by looking for chargeability contours that show a high value. The chargeability values in the IP survey are not basically a direct response from the gold metal, but rather the response was given by the sulfide minerals. The sulfide complexion ( $\mathrm{HS}^{-}$and $\mathrm{H}_{2} \mathrm{~S}$ ) is a ligand capable of transporting large amounts of metal minerals, including gold. The process of boiling and increasing the $\mathrm{pH}$ in a depositional environment causes a reduction in HS activity so that metal sulfides are precipitated. The above statement makes it clear that the determination of gold-mineralized zones can be done by looking for the high chargeability response caused by sulfide minerals as the metal carrier. 


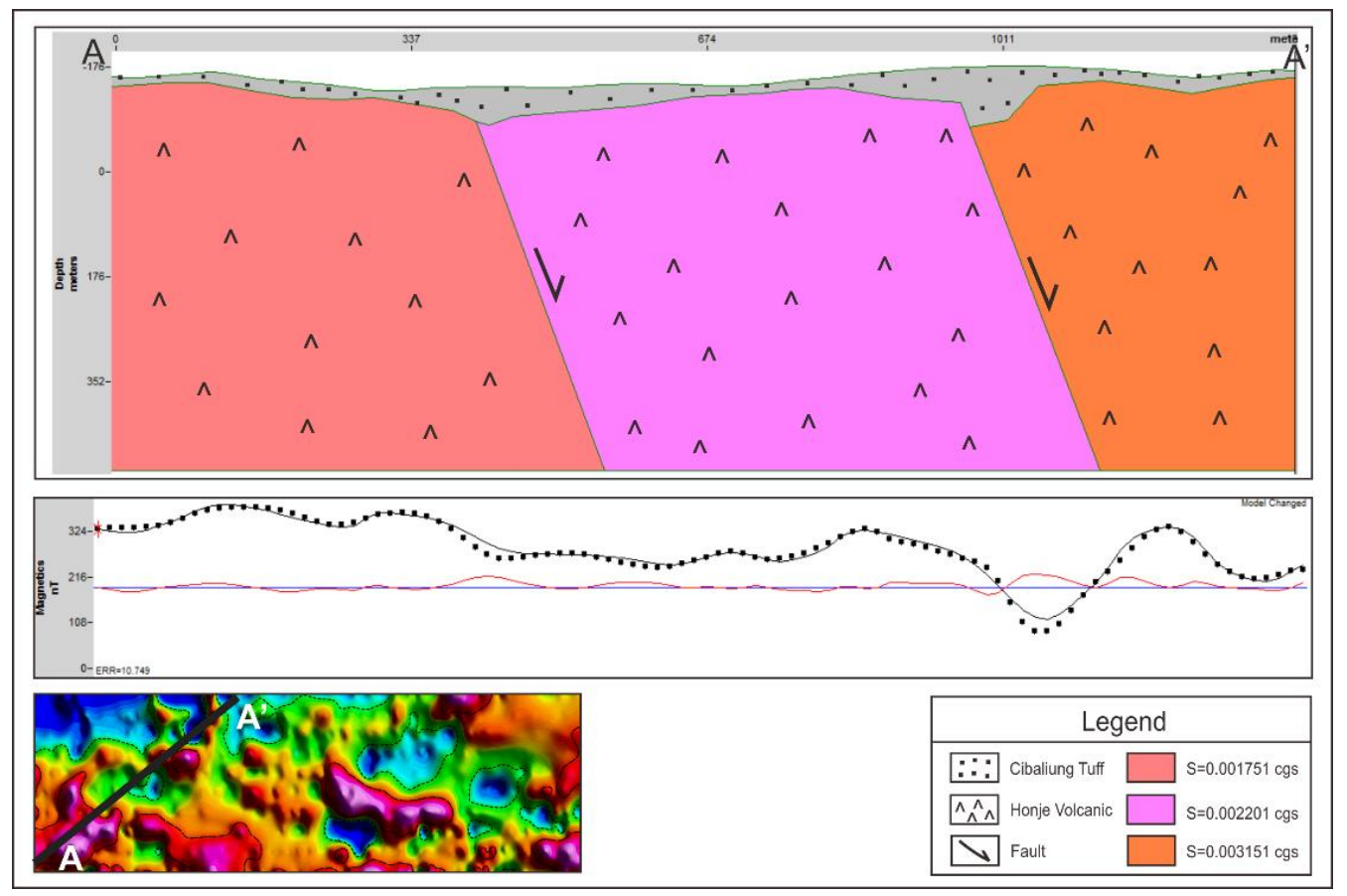

Figure 10. The 2.5D model with several rock blocks having susceptibility $0.001751 \mathrm{cgs}, 0.002201 \mathrm{cgs}$, and $0.003151 \mathrm{cgs}$. The rock block is separated by several normal faults which become the fluid circulation pathway and covered by tuff Cibaliung with susceptibility of $0.000001 \mathrm{cgs}$

Analysis of the entire IP section shows the resistivity and chargeability responses ranging from $0.318 \Omega . m$ to $17615 \Omega$.m and $0 \mathrm{~ms}$ to 728 ms. The resistivity and chargeability values are then classified into three categories, low, medium, and high (Table 2). The analysis of resistivity data shows that $98.317 \%$ of the data is in the range of $0.318 \Omega . \mathrm{m}$ to $300 \Omega$.m, where $300 \Omega$.m then will be used as the maximum limit for the color scale of the resistivity section. Meanwhile, the maximum limit for the color scale of the IP section is $120 \mathrm{~ms}$, considering that $96.41 \%$ of the data are in the range of 0 $\mathrm{ms}$ to $120 \mathrm{~ms}$.

Table 2. Classification of rock resistivity and chargeability values in the survey area

\begin{tabular}{ccc}
\hline $\begin{array}{c}\text { Resistivity } \\
(\Omega . m)\end{array}$ & $\begin{array}{c}\text { Chargeability } \\
(\mathrm{ms})\end{array}$ & Category \\
\hline $1-50$ & $0-30$ & Low \\
$51-200$ & $31-80$ & Medium \\
$>200$ & $>81$ & High \\
\hline
\end{tabular}

Interpretation of the gold-bearing vein zones in the resistivity and chargeability sections begins by reviewing the geological structure of the study area. The host rock of gold mineralization which is andesite and volcanic breccia basically have high resistivity and low chargeability values. The hydrothermal fluid that circulating through the rock fractures results in the formation of altered minerals such as clay and silica around the permeable zone (fractures). As a pressure, temperature and $\mathrm{pH}$ change, sulfide minerals that bind gold will then be deposited in the alteration zone and the residual silica will be deposited at a location closer to the surface. The presence of residual silica will usually form a high topography and provide a very high resistivity response.

Geological studies that have been carried out by several previous authors have shown that gold mineralization in the Cibaliung area occurs in veins embedded in clay minerals and associated with sulfide minerals. The presence of clay and sulfide minerals will decrease the resistivity value of the rock so that the vein zone containing gold will form a low resistivity pattern surrounded by high resistivity. Meanwhile, the chargeability response in the IP section is only significantly affected by sulfide minerals, so that the presence of gold is interpreted to be in the high chargeability contour. A brief interpretation of the resistivity and chargeability data can be seen in Table 3. 
Table 3. Interpretation of resistivity and chargeability values in the study area.

\begin{tabular}{ccl}
\hline $\begin{array}{c}\text { Resistivity } \\
(\Omega . \mathrm{m})\end{array}$ & $\begin{array}{c}\text { Chargeability } \\
(\mathrm{ms})\end{array}$ & \begin{tabular}{l} 
Interpretation \\
\hline Low
\end{tabular} \\
Low & $\begin{array}{l}\text { Clay altered rock / } \\
\text { Water saturated } \\
\text { rock }\end{array}$ \\
High & Low & $\begin{array}{l}\text { Fresh rock/silica } \\
\text { sinter } \\
\text { Gold mineralization } \\
\text { in clay } \\
\text { Gold mineralization } \\
\text { in silica }\end{array}$ \\
\hline
\end{tabular}

Analysis of gold-bearing vein zones takes an example on an IP section line 4A (Figure 11). The gold-bearing vein zones are interpreted to be in the contour of medium to high chargeability and low resistivity. Observation on IP line 4A shows that there are three main mineralized zones characterized by medium to high chargeability values $(51 \mathrm{~ms}-502.92$ $\mathrm{ms})$ and low resistivity $(<50 \Omega . \mathrm{m})$. The IP response is given by the sulfide minerals present in the vein and increases at higher concentrations. The concentration of sulfide minerals can be influenced by the level of rock permeability, where rocks with high fracture density will be easier to be infiltrated by fluid and then form mineralized vein zones.
Observation on IP line 4A shows a low resistivity zone which is much larger than the high chargeability zone. This phenomenon can be caused by extensive clay alteration and the presence of rock layers saturated with groundwater. Analysis of gold-bearing vein zones is difficult to perform on resistivity data, since the low resistivity response may be given by non-sulfide materials. Therefore, the delineation of the gold-bearing vein zones will only be carried out through chargeability data.

The correlation carried out at 20 IP sections shows a narrow pattern on the high to medium chargeability contours (Figure 12). The narrow pattern is interpreted as a zone of gold-bearing veins with various sulfide concentrations. The continuity of high chargeability contours in the correlated IP section is basically not the response given by a single vein, but by the cumulative mineralized veins. The analysis of the IP section shows that the chargeability value is weakened at several locations and is followed by a reduction in the anomaly geometry. This phenomenon is interpreted as a result of a decrease in fracture density or an accumulation of clay material in rock space so that the permeability is reduced and the fluid carrying the sulfide can not infiltrate properly.

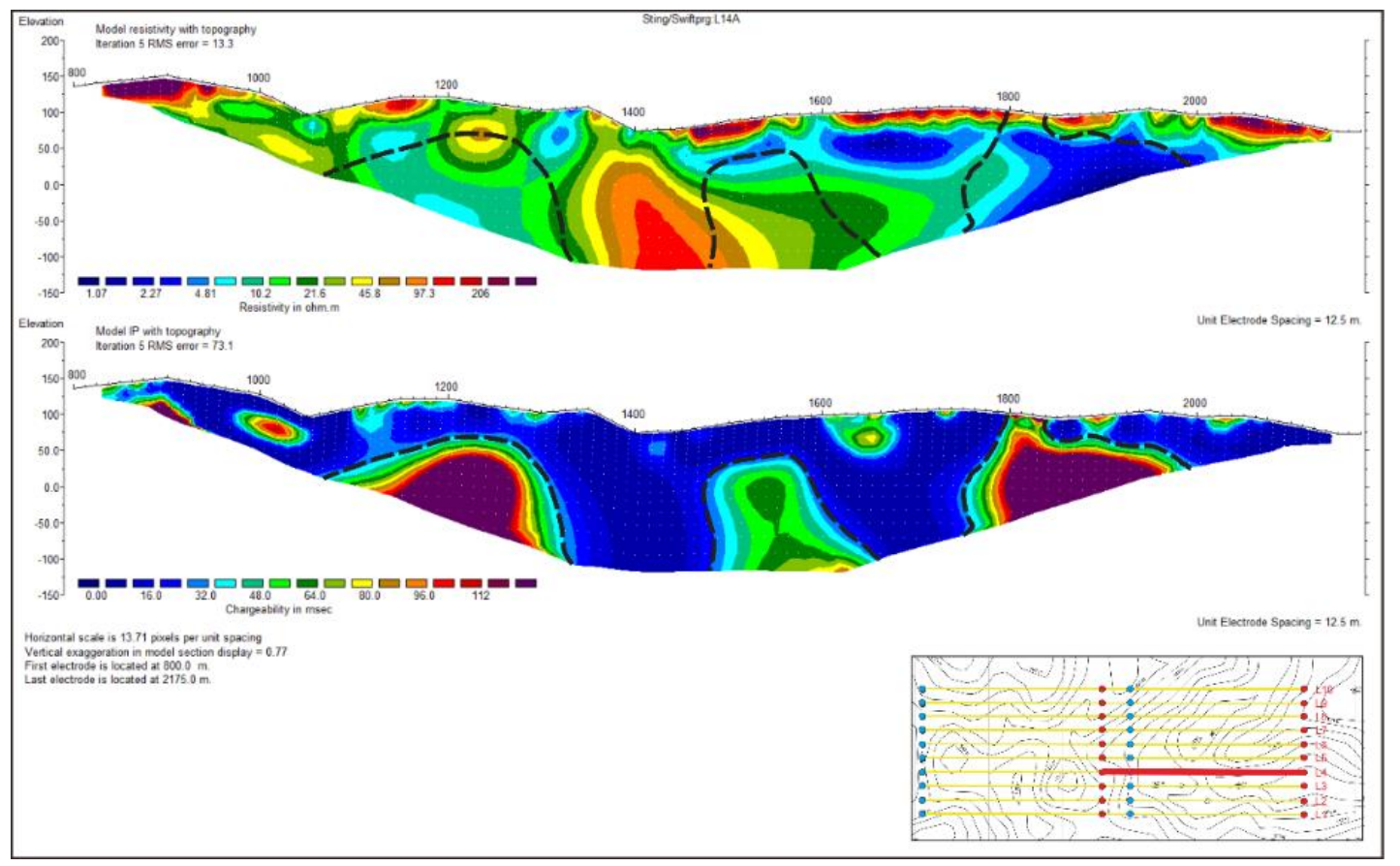

Figure 11 . The 2D resistivity and IP section of line $4 A$ in the study area with the presence of three main prospect zones which are thought to contain gold 


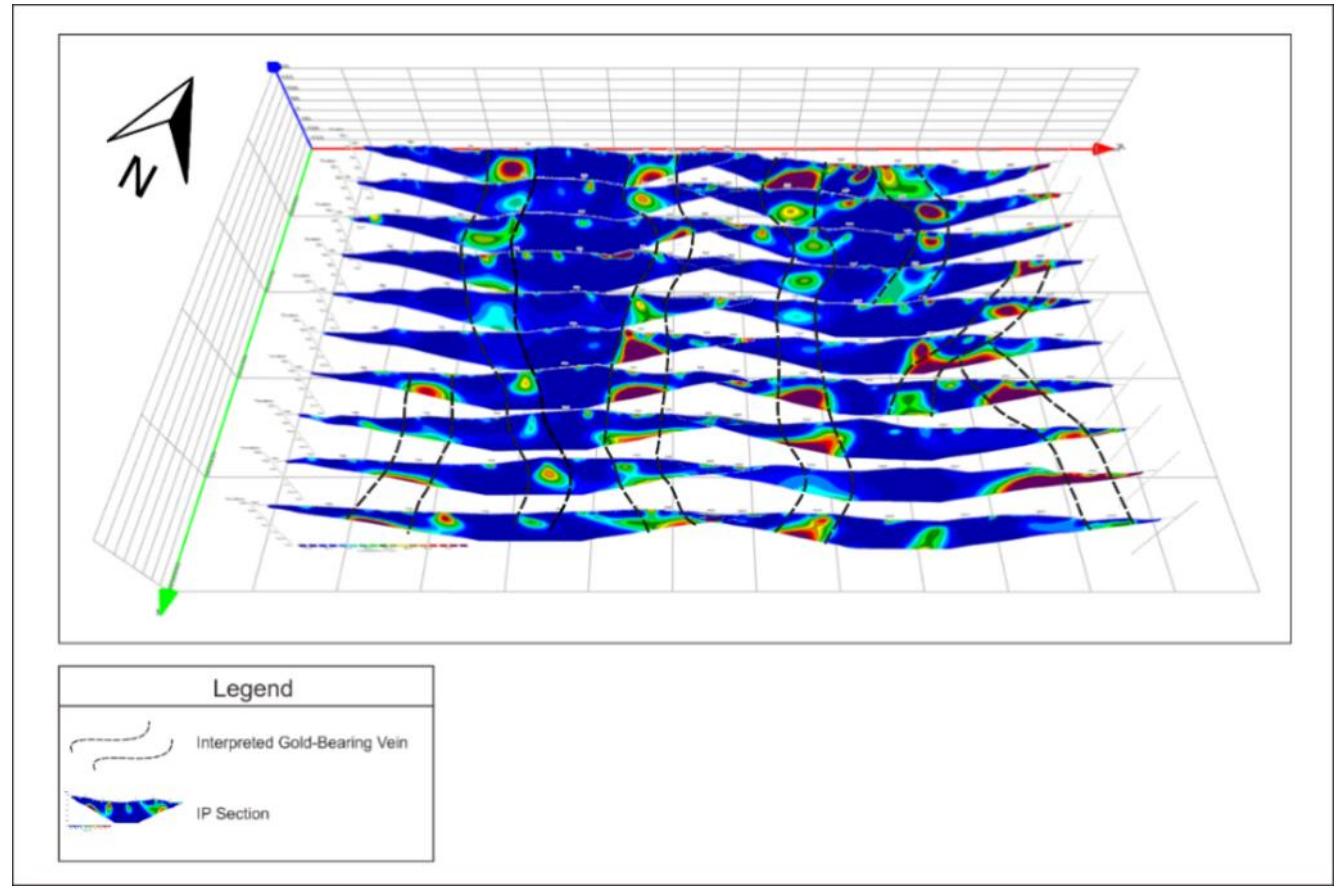

Figure 12. Delineation of gold-bearing vein zones in the study area. There are seven oreinted northwest gold-bearing veins

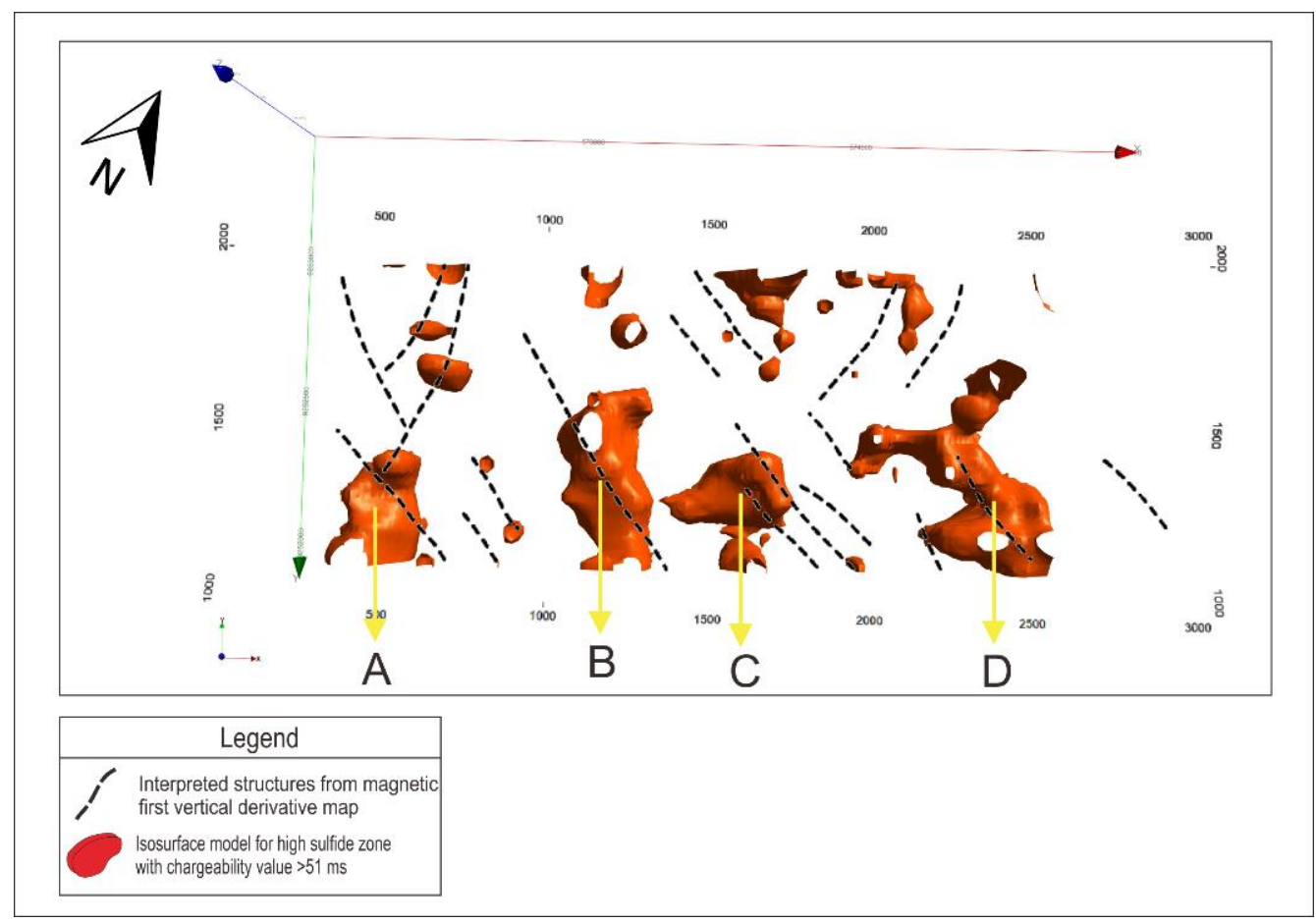

Figure 13. 3D isosurface model of mineralized bodies correlated to structures interpreted on the first vertical derivative map

The geometry and distribution of mineralized zones in the study area are determined by creating a 3-D isosurface model using chargeability data. The 3-D mineralization model is then combined with the interpreted structure on the FVD map, which aims to test 
the coherency of magnetic and IP data, as well as to narrow the zone of interest (Figure 13). The model shows that there are four main zones that are considered as gold prospect areas, namely zone $A, B, C$, and $D$. The model below also proves that the gold mineralization tends to occur around the northwest trending structures.

\section{CONCLUSION}

Magnetic data indicate that gold-mineralized zones are generally distributed in areas with magnetic anomaly responses ranging from $37 \mathrm{nT}$ to $420 \mathrm{nT}$ and tend to be associated with northwest trending structures. Mineralization is found in four main prospect zones with chargeability values that fall into the medium to high category (> $51 \mathrm{~ms}$ ) and the dominant resistivity values fall into the

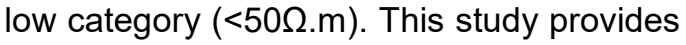
recommendations for exploration drill points located in four main zones that are strongly suspected to contain gold prospects, zone A, $\mathrm{B}, \mathrm{C}$, and D.

\section{ACKNOWLEDGMENTS}

The author would like to thank the Department of Geophysical Engineering UPNYK for contributing to the data analysis process and PT Antam Unit Geomin for being willing to provide data in this research. Gratitude also goes to Mr. Firdaus Maskuri MT who has assisted the author in conducting geological analysis, so that this paper has a deeper study in geology.

\section{REFERENCE}

Airo, M.-L. (2002) 'Aeromagnetic and aeroradiometric response to hydrothermal alteration', Surveys in Geophysics, 23, pp. 273-302. doi: 10.1023/A:1015556614694.

Angeles, C. A., Prihatmoko, S. and Walker, J. S. (2002) 'Geology and alterationmineralization characteristics of the Cibaliung epithermal gold deposit, Banten, Indonesia', Resource Geology, 52(4), pp. 329-339. doi: 10.1111/j.17513928.2002.tb00143.x.
Blakely, R. J. (1996) Potential theory in gravity and magnetic applications. Cambridge: Cambridge University Press.

Dobrin, M. B. and Savit, C. H. (1988) Introduction to geophysical prospecting. 4th edn. New York: McGraw-Hill.

Al Hapsi, S. I. (2017) Geologi dan kontrol struktur geologi terhadap alterasi dan mineralisasi daerah Rancawaru dan sekitarnya, Kecamatan Cimanggu, Kabupaten Pandeglang, Provinsi Banten. Universitas Pembangunan Nasional 'Veteran' Yogyakarta.

Harijoko, A., Ohbuchi, Y., Motomura, Y., Imai, A. and Watanabe, K. (2007) 'Characteristics of the Cibaliung gold deposit: Miocene low-sulfidation-type epithermal gold deposit in Western Java, Indonesia', Resource Geology, 57(2), pp. 114-123. doi: 10.1111/j.1751-3928.2007.00011.x.

Hinze, W. J., von Frese, R. R. B., Von Frese, R. and Saad, A. H. (2013) Gravity and magnetic exploration. Cambridge: Cambridge University Press.

Kang, S. and Oldenburg, D. W. (2018) 'Time domain electromagnetic-induced polarisation: Extracting more induced polarisation information from grounded source time domain electromagnetic data', Geophysical Prospecting, 66(S1), pp. 74-86. doi: 10.1111/13652478.12600 .

Kurniawan, A. and Hartono (2010) 'Karakterisasi mineralisasi permukaan vein Cikoneng daerah Cibaliung-Banten', in Arif, J., Krisnayanti, B. D., and Setyandhaka, D. (eds) The 39th IAGI Annual Convention and Exhibition. Lombok: HAGI - IAGI IAFMI - IATMI, pp. 11.1-14.

Pirajno, F. (1992) Hydrothermal mineral deposits. Berlin, Heidelberg: Springer Berlin Heidelberg. doi: 10.1007/978-3-64275671-9.

Telford, W. M., Geldart, L. P. and Sheriff, R. E. (1991) Applied geophysics. 2nd edn. Cambridge: Cambridge University Press.

Ward, S. H. (1990) 'Resistivity and induced polarization methods', in Ward, S. H. (ed.) Geotechnical and Environmental Geophysics. Tulsa, Oklahoma: Society of Exploration Geophysicists, pp. 147-190. doi: 10.1190/1.9781560802785.ch6. 